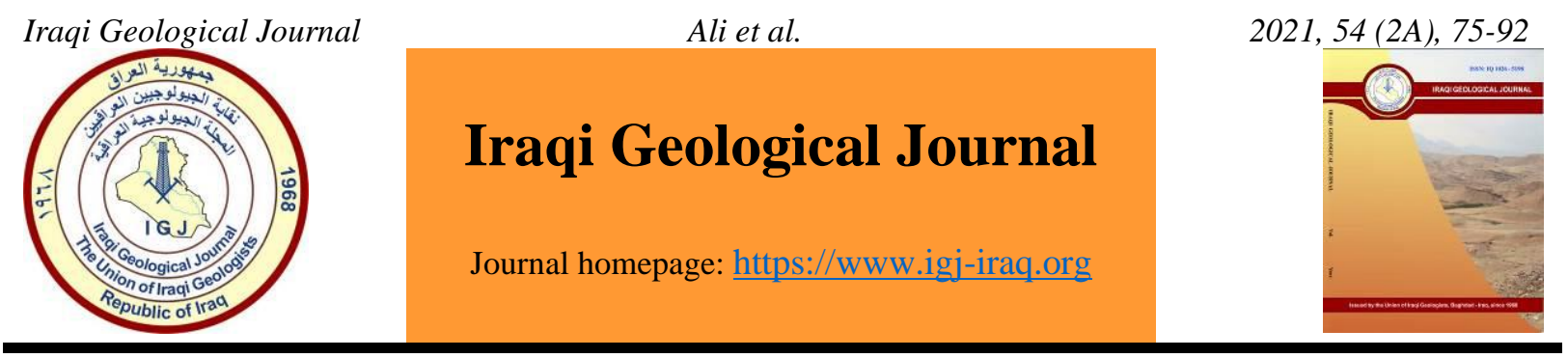

\title{
Geochemical Distribution of Some Heavy Metals in Agricultural Soil and Their Environmental Impacts in Kirkuk, Northern Iraq
}

\author{
Abbas R. Ali ${ }^{1}{ }^{*}$, Torhan M. Al-Mufti ${ }^{2}$ and Chinar M. Taqi ${ }^{1}$ \\ 1 Department of Applied Geology, College of Science, University of Kirkuk, Kirkuk, Iraq \\ 2 Council of Ministers, Baghdad, Iraq \\ * Correspondence: abbaskervanci@uokirkuk.edu.iq
}

Received: 29 January 2021; Accepted: 26 April 2021; Published: 31 July 2021

\begin{abstract}
This study is based on agricultural soil samples which are collected along three traverses (A, B, C), near the gypsum quarries located near the village of Bajwan north of Kirkuk city, to conduct a geochemical analysis and determining some heavy elements $(\mathrm{Co}, \mathrm{Cr}, \mathrm{Ni}, \mathrm{Cu}, \mathrm{Sr}, \mathrm{Pb}, \mathrm{Cd})$ levels in the surface and subsurface soil horizons, and to indicate the potential sources of contamination with these elements. Accordingly, 30 samples were collected (six samples from travers A, five samples from travers B, and four samples from travers C) from the soil for each of the surface and subsurface levels. The results showed that the average concentrations of most studied elements increased in the subsurface soil compared to the surface soil, as a result of the influence of different geological and environmental conditions on the distribution of these elements in different soil horizons. The concentrations of the studied elements $(\mathrm{Co}, \mathrm{Ni}, \mathrm{Cd})$ are more than their natural concentrations when compared to the natural abundance of these elements in the earth's crust, which indicates an increase in the concentration of these elements in the soil as a result of the proximity of the study area to the oil industries activities, causing the emission of high concentrations of heavy elements. As well as the traffic density of vehicles, causing the release of high concentrations of some elements. The geo accumulation factor (Igeo) indicates that most of the soil samples within different horizons of most of the heavy elements are uncontaminated to moderately contaminated, and moderately contaminated for cadmium. Also, by calculating the RI and the environmental risk factor (Er), it was found that the relative content of cadmium in soil samples recorded a considerable potential ecological risk to a high potential ecological risk. This indicates high affinity of cadmium in the soil as its infiltration into the subsurface layers.
\end{abstract}

Keywords: Geochemistry; Heavy metals; Environmental pollution; Environmental hazard index; Geo accumulation factor; Kirkuk

\section{Introduction}

Heavy elements are one of the most important environmental pollutants because of their toxicity and their long durability, where they can be transported to long distances from their areas of origin (Edem et al, 2002). Large quantities of elements are released into the environment through human activities, and these elements are highly reactive chemically in the environment, and humans can be exposed to high levels of toxic elements through the three traverses: inhalation, skin contact, and ingestion (Zovko and Romic, 2011). In urban and industrial environments there are many probable

DOI: $10.46717 /$ igj.54.2A.6Ms-2021-07-27 
sources of contamination with harmful substances, including heavy elements, especially combustion processes in industry and transportation. Moreover, manufacturing activities to extract and industrial mineral products may release large amounts of pollutants into the atmosphere and soil, and the adjacent waters (Zovko and Romic, 2011). The main elements available in the soil are usually oxides, hydroxides, oxy-hydroxides, with the exception of silicon oxide and some titanium oxides, and are mostly due to the primary rock elements, from which most of the oxides in the soil are formed (Scheinost, 2005).

The current research aims to study the geochemical distribution of heavy elements $(\mathrm{Co}, \mathrm{Cr}, \mathrm{Ni}, \mathrm{Cu}$, $\mathrm{Sr}, \mathrm{Pb}, \mathrm{Cd}$ ) in the soil, and to identify the geochemical relationships by using the statistical program (SPSS, V22) to conducting some statistical operations Multivariate Statistical Analysis (MSA), to know the geochemical behavior of trace elements in surface and subsurface soil samples with other chemical components and probable sources there in order to identify about the role of natural resources and the impact of human activities in increasing the concentration of trace elements in the surface and subsurface soil, as well as assessing environmental impacts of heavy elements within the different horizons of the soil and determine the health risks (carcinogen and non-carcinogenic) it has on the health of residential communities located in the area.

\section{Location and Geological Setting of Study Area}

The study area is represented by the agricultural soils located near the gypsum crops out and near to the oil fields in the northwestern region of the city of Kirkuk and near the village of Bajwan between

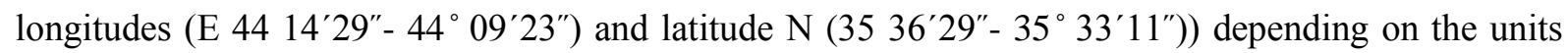
squared (UTM) and as shown in Fig.1. Its average height is $319 \mathrm{~m}$ above sea level, and it is about 22.5 $\mathrm{km}$ from Kirkuk center in the northwestern part.

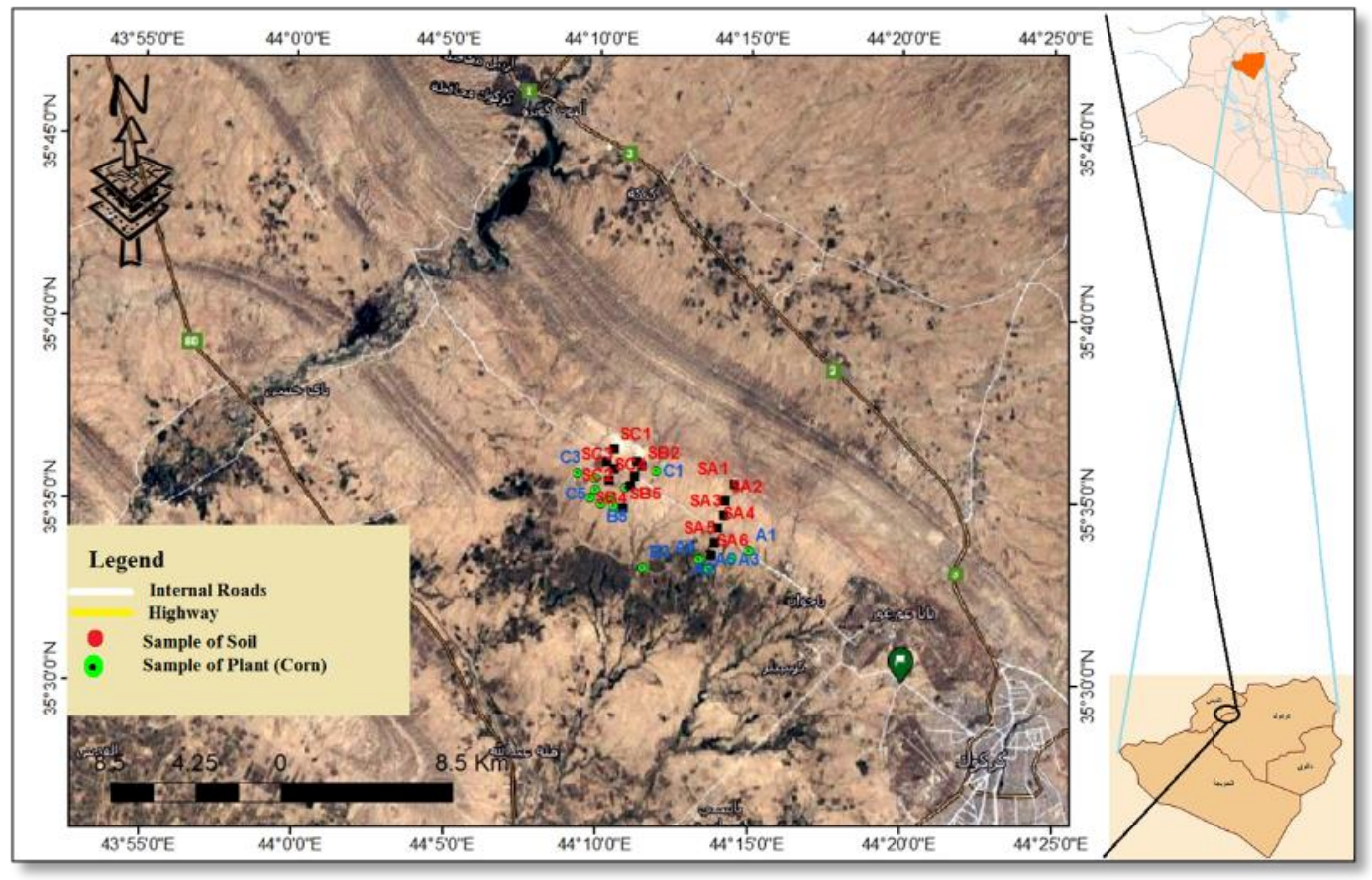

Fig.1. A map of the study area showing the locations of soil samples

As the gypsum quarries of the rock outcrops are located on the northeastern wing of the Fatha fold within the study area. The lower contact of the Fatha Formation with the Jeribe Formation is unconformity, while on the upper side its limits with the Injana Formation (Upper Miocene) (Bellen et al., 1959). The gypsum layer is the boundary between the Fatha formation and the Injana formation 
(Kassab and Jassim, 1980). The basic units of the Injana formation are clastic rock, which consists of sandstone, siltstone, shale, and red or brown mudstone layers, and a thin layer of $20 \mathrm{~cm}$ thickness from gypsum. Different geological formations are exposed in Kirkuk and some parts of them are covered with recent sediments ranging in age from (Middle Miocene-Holocene) (Fig. 2).

On the upper side Injana formation limited by the Muqdadia Formation (lower Pliocene), this formation consists of gravel and sandstone deposits with red mudstone, and sandstone is often cross bedding with a gradient in the composition components lower parts of the formation to the top from the size of the silt to various sizes of gravel and boulder are known as conglomerates (Buday, 1980). As for the Bai Hassan Formation of the (Pliocene-Pleistocene), which has general characteristics similar to that of Muqdadia Formation, it is composed of successions of claystone, conglomerate and siltstone, and is often covered with sediments of the Quaternary and Holocene. (Buday, 1980; Jassim and Goff, 2006).

\section{Materials and Methods}

Thirty soil samples were collected with fifteen samples for each of the surface areas with a depth of 0-20 cm and the subsurface area with a depth of 20-40 cm (Zhao et al., 2021), for the soil distributed on three travers represented by A, B and C as shown in Fig.1, Table 1, with six surface samples symbolized by SA along the first travers and six subsurface travers symbolized by SbA and the distance between each sample was approximately $150 \mathrm{~m}$ in a travers in the direction of the Bajwan District road, four samples before the road and two after the road were taken. The SA6 surface and SbA6 subsurface were considered as standard samples for chemical compositions, being the farthest from gypsum quarries and for being far from the influence of gypsum dust, which is apparent through satellite images.

Also, five surface samples, symbolized by SB and five other subsurface samples, symbolized by $\mathrm{SbB}$ were taken in different places along with the second travers. In addition to, three samples were collected before the road and two samples after the road. Four surface samples, symbolized by SC and four subsurface samples, symbolized by $\mathrm{SbC}$ were taken in different places along the third travers, where three samples were taken before the road and one sample after the road, taking one sample of quarry plaster as a standard sample and its symbol (Gy). The distance between the first and second quarries was about $4.700 \mathrm{~km}$, and the second quarry was about $800 \mathrm{~m}$ away from the third, as shown in Fig.1. Elements concentration was determined by using polarized energy dispersive XRF. The spectrometer used in this study was Spectro XLAB 2000 PEDXRF at the Earth Science Research and Application Center (YEBIM), Ankara, Turkey.

\section{Results and Discussion}

\subsection{Heavy Elements Geochemistry in the Soil of the Study Area}

Some trace elements are basic elements but become toxic when present above a certain concentration level because the elements often occur in ionized forms in the soil (Singh et al., 2018; Davenport, 2020). For these reasons, soil geochemical monitoring is important in order to assess the natural content of the elements in the soil, related to the source material and potential enrichment due to human activities (Barbieri et al., 2015).

The results of the geochemical analyzes of soil samples in the surface and subsurface horizon shown in Tables 2, 3 and Fig. 3 indicate that the average concentration of cobalt (Co) is 16.09 ppm in the surface soil, and $16.69 \mathrm{ppm}$ in the subsurface soil, and in all the studied samples is higher than its concentration rates in the soil ranged (1-40ppm) according to (Alloway, 1990), as well as from concentrations in the earth's crust according to (Kabata-Pendias and Mukherjee, 2007), which is (10-12ppm). This may be due to anthropogenic sources of pollution (Srinivas et al., 2009; Al-Obeidi and Al-Jumaily, 2020), as the industrial facilities and the North Oil Company spread near to the site of the 
study area. Also indicated (Oladeji and Saeed, 2015) the availability of high levels of cobalt in industrial areas.

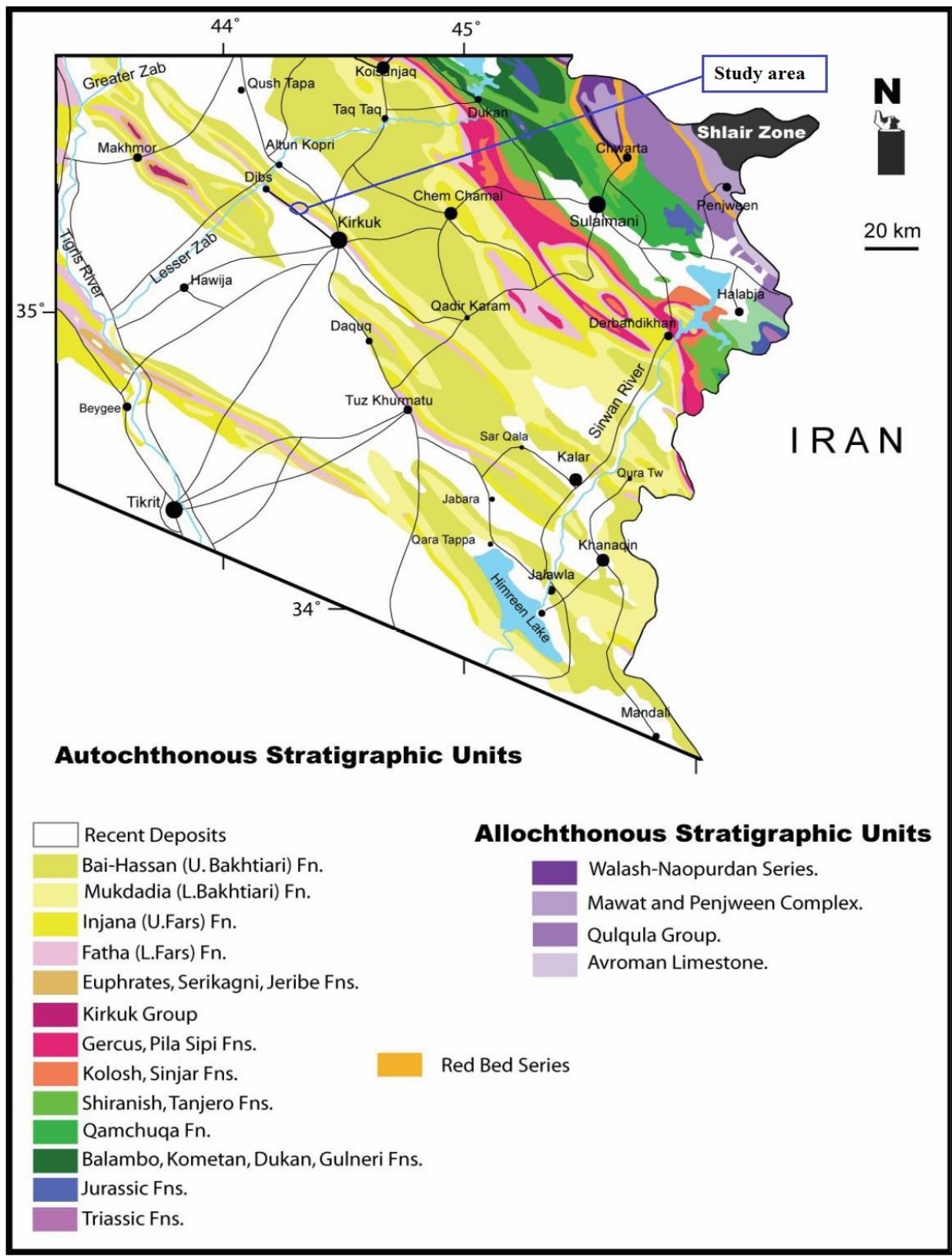

Fig.2. Geological map of northern Iraq showing the location of the studied area

It was also observed that the concentration of cobalt in the subsurface samples more than the surface samples may be because filtration process and that all the studied samples were less than the surface selected standard sample (SA6) of (18.22ppm) and subsurface (SbA6) of (18.36ppm). The natural and non-disturbed soils allow water to filter, which acts as a suitable shelter for trace elements, such as particles absorbing water-borne elements along with the soil and trapped in different layers. In the urban environment, rainwater filtering is low compared to the semi-urban environment because of an absence of large areas covered with soil (Wong et al., 2006).

The results appear that with moving away from the gypsum quarries, the concentrations of the Co, $\mathrm{Ni}, \mathrm{Cd}$ elements increase. This is because of the action of the winds in the study area, where the wind direction is northeast, changes in speed and direction of the winds cause the deposition of dust and particles, which may lead to preferential sedimentation of the elements. The dust and particles on paved 
surfaces can be easily suspended by wind, and there is no doubt that this phenomenon works as a sorting mechanism separating the coarse particles from fine particles (Al-Chalabi and Hawker, 1997). In addition, coarse particles are deposited near quarries while fine particles are deposited further away from them.

Table 1. Sites for taking soil samples in the study area

\begin{tabular}{|c|c|c|c|}
\hline Sample No. & Longitude & latitude & Height (m) \\
\hline \multicolumn{4}{|c|}{ Travers A } \\
\hline $\mathrm{SA} 1, \mathrm{SbA} 1$ & $35^{\circ} 35^{\prime} 21 " \mathrm{~N}$ & $44^{\circ} 14^{\prime} 29 " \mathrm{E}$ & 335 \\
\hline $\mathrm{SA} 2, \mathrm{SbA} 2$ & $35^{\circ} 35^{\circ} 02 " \mathrm{~N}$ & $44^{\circ} 14^{\prime} 19^{\prime \prime} \mathrm{E}$ & 318 \\
\hline $\mathrm{SA} 3, \mathrm{SbA} 3$ & $35^{\circ} 34^{`} 36^{\prime \prime N}$ & $44^{\circ} 14^{`} 10^{\prime \prime} \mathrm{E}$ & 317 \\
\hline $\mathrm{SA} 4, \mathrm{SbA} 4$ & $35^{\circ} 3415 " \mathrm{~N}$ & $44^{\circ} 14^{`} 033^{\prime \prime} \mathrm{E}$ & 309 \\
\hline SA5, SbA5 & $35^{\circ} 33^{\circ} 47^{\prime \prime N}$ & $44^{\circ} 13{ }^{`} 55^{\prime \prime} \mathrm{E}$ & 301 \\
\hline SA6, SbA6 & $35^{\circ} 33^{\prime} 32 \mathrm{~N}$ & $44^{\circ} 13^{\circ} 41^{\prime \prime} \mathrm{E}$ & 299 \\
\hline \multicolumn{4}{|c|}{ Travers B } \\
\hline SB1, SbB1 & $35^{\circ} 36^{\circ} 08^{\prime \prime} \mathrm{N}$ & $44^{\circ} 11{ }^{\prime} 20 " \mathrm{E}$ & 316 \\
\hline SB2, SbB2 & $35^{\circ} 36^{\circ} 00 " \mathrm{~N}$ & $44^{\circ} 1126{ }^{\prime \prime} \mathrm{E}$ & 313 \\
\hline SB3, SbB3 & $35^{\circ} 35^{\circ} 47^{\prime \prime} \mathrm{N}$ & $44^{\circ} 1118$ "E & 305 \\
\hline SB4, SbB4 & $35^{\circ} 35^{\prime} 23 " \mathrm{~N}$ & $44^{\circ} 11{ }^{\prime} 06^{\prime \prime} \mathrm{E}$ & 308 \\
\hline SB5, SbB5 & $35^{\circ} 344^{`} 52 \mathrm{~N}$ & $44^{\circ} 10 ` 58 \quad \mathrm{E}$ & 302 \\
\hline \multicolumn{4}{|c|}{ Travers C } \\
\hline $\mathrm{SC} 1, \mathrm{SbC} 1$ & $35^{\circ} 3629 " \mathrm{~N}$ & $44^{\circ} 10 ` 30 " \mathrm{E}$ & 316 \\
\hline $\mathrm{SC} 2, \mathrm{SbC} 2$ & $35^{\circ} 3613 " \mathrm{~N}$ & $44^{\circ} 10 ` 27^{\prime \prime} \mathrm{E}$ & 306 \\
\hline $\mathrm{SC} 3, \mathrm{SbC} 3$ & $35^{\circ} 36^{\circ} 06^{\prime \prime} \mathrm{N}$ & $44^{\circ} 10 ` 333^{\prime \prime} \mathrm{E}$ & 310 \\
\hline $\mathrm{SC} 4, \mathrm{SbC} 4$ & $35^{\circ} 35^{\circ} 45^{\prime \prime} \mathrm{N}$ & $44^{\circ} 10 ` 28^{\prime \prime} \mathrm{E}$ & 301 \\
\hline
\end{tabular}

Table 2. The concentrations, ranges, and rates of trace elements per unit ( $\mathrm{ppm})$ for the surface soil samples for the study area

\begin{tabular}{|c|c|c|c|c|c|c|c|}
\hline Sample No. & Co & $\mathbf{N i}$ & $\mathrm{Cu}$ & $\mathrm{Cr}$ & $\mathrm{Sr}$ & Cd & $\mathbf{P b}$ \\
\hline SA1 & 14.27 & 82.39 & 22.59 & 68.05 & 562.34 & 0.23 & 13.89 \\
\hline SA2 & 14.31 & 87.43 & 23.59 & 74.67 & 422.83 & 0.34 & 13.92 \\
\hline SA3 & 13.97 & 83.12 & 22.87 & 68.12 & 658.94 & 0.51 & 9.75 \\
\hline SA4 & 15.99 & 92.87 & 27.12 & 70.14 & 458.91 & 0.19 & 14.32 \\
\hline SA5 & 17.29 & 125.87 & 27.11 & 83.69 & 725.61 & 0.44 & 13.46 \\
\hline${ }^{*}$ SA6 & 18.22 & 130.44 & 28.53 & 85.77 & 289.16 & 0.18 & 14.89 \\
\hline SB1 & 15.57 & 97.18 & 23.08 & 69.89 & 654.79 & 0.18 & 12.55 \\
\hline SB2 & 14.72 & 89.67 & 22.38 & 67.85 & 572.49 & 0.28 & 11.98 \\
\hline SB3 & 16.69 & 109.78 & 25.67 & 77.29 & 312.55 & 0.51 & 12.65 \\
\hline SB4 & 17.78 & 119.88 & 26.95 & 85.77 & 272.85 & 0.52 & 13.74 \\
\hline SB5 & 18.02 & 119.78 & 26.44 & 82.97 & 455.68 & 0.51 & 13.67 \\
\hline SC1 & 15.98 & 88.39 & 24.19 & 79.85 & 575.36 & 0.38 & 14.22 \\
\hline $\mathrm{SC} 2$ & 13.89 & 82.29 & 23.11 & 68.71 & 495.84 & 0.47 & 9.57 \\
\hline SC3 & 16.85 & 92.45 & 26.89 & 85.45 & 702.18 & 0.55 & 15.02 \\
\hline $\mathrm{SC} 4$ & 17.92 & 99.38 & 27.98 & 90.22 & 308.19 & 0.45 & 15.21 \\
\hline Avg. & 16.09 & 100.06 & 25.23 & 77.23 & 497.85 & 0.38 & 13.26 \\
\hline Range & $\begin{array}{c}13.89 \text { - } \\
8.22\end{array}$ & $\begin{array}{l}82.29- \\
130.44\end{array}$ & $\begin{array}{c}22.38- \\
28.53\end{array}$ & $\begin{array}{c}67.85- \\
90.22\end{array}$ & $\begin{array}{c}272.85- \\
725.61\end{array}$ & $\begin{array}{c}0.18- \\
0.55\end{array}$ & $\begin{array}{l}9.57- \\
15.21\end{array}$ \\
\hline Background & $* * 1-40$ & $* * * 16$ & $20-30 *$ & $1-100^{*}$ & --- & $* * * 1.9$ & $* * 10-20$ \\
\hline$* * * *$ Erath crust & 10 to 12 & 20 & $25-75$ & $125-185$ & $260-730$ & $0.1-0.2$ & 15 \\
\hline **Alloway, 1990 & *Standard & $* * *$ Al &, 2000 & $* * * * \mathbf{K}$ & a-Pendias & Mukhe &, 2007 \\
\hline
\end{tabular}

Whereas, the average concentration of nickel $(\mathrm{Ni})$ was $100.06 \mathrm{ppm}$ in the surface soil sample, and $105.05 \mathrm{ppm}$ in the subsurface soil. It is observed that the rate of nickel concentration in all the studied 
samples is higher than its global rates according to (Alloway, 2000), and the rate in the earth's crust according to Kabata-Pendias and Mukherjee (2007), which is $16 \mathrm{ppm}$ and $20 \mathrm{ppm}$ respectively. And as (Ibrahim et al., 2018) showed that the industrial activity may cause to increase the nickel contain in to the sediments. It is also observed that the element concentration in all the studied samples is less than the two selected standard samples they are surface (SA6) is $130.44 \mathrm{ppm}$ and the subsurface (SbA6) is $132.59 \mathrm{ppm}$. It may be related to the high application of fertilizers and herbicides in agriculture, which is an important source of nickel in the soil (Chauhan et al., 2008; Yasmeen et al. 2010; Al-Jumaily and Hasseb, 2021). Or it is a result of the sulfur rich geological formations, such as the Fatha Formation exposed in the study area which contain gypsum quarries in the region, nickel exhibits high geochemical affinity with sulfur under reduce conditions, and the element is concentrated in rich organic contain clays and precipitates as sulfide (Rankama and Sahama, 1950; Butu, 2013). The total concentration of nickel may be directly related to its concentration in source rocks and weathering processes (Mitchell, 1964).

Table 3. The concentrations, ranges, and rates of trace elements per unit (ppm) for the sub surface soil samples for the study area

\begin{tabular}{|c|c|c|c|c|c|c|c|}
\hline Sample No. & Co & $\mathbf{N i}$ & $\mathrm{Cu}$ & $\mathrm{Cr}$ & $\mathrm{Sr}$ & Cd & $\mathbf{P b}$ \\
\hline SbA1 & 14.39 & 95.14 & 27.05 & 74.29 & 612.37 & 0.19 & 12.75 \\
\hline $\mathrm{SbA2}$ & 16.26 & 96.72 & 27.42 & 77.25 & 774.2 & 0.21 & 12.88 \\
\hline $\mathrm{SbA3}$ & 14.33 & 87.49 & 23.66 & 69.75 & 325.49 & 0.23 & 15.12 \\
\hline SbA4 & 16.49 & 99.82 & 26.85 & 77.89 & 498.31 & 0.22 & 12.92 \\
\hline SbA5 & 18.05 & 127.33 & 27.22 & 79.34 & 354.19 & 0.48 & 14.78 \\
\hline *SbA6 & 18.36 & 132.59 & 27.89 & 90.36 & 622.38 & 0.42 & 12.33 \\
\hline SbB1 & 16.33 & 102.34 & 25.74 & 77.21 & 708.19 & 0.56 & 10.87 \\
\hline SbB2 & 14.87 & 96.37 & 23.87 & 69.61 & 675.89 & 0.45 & 12.99 \\
\hline SbB3 & 18.11 & 120.37 & 27.68 & 89.75 & 398.79 & 0.22 & 12.28 \\
\hline SbB4 & 18.06 & 123.71 & 27.96 & 90.98 & 459.87 & 0.48 & 13.85 \\
\hline SbB5 & 17.95 & 122.36 & 27.98 & 91.25 & 402.15 & 0.52 & 14.05 \\
\hline $\mathrm{SbC1}$ & 14.43 & 85.17 & 23.48 & 69.18 & 566.91 & 0.54 & 11.57 \\
\hline $\mathrm{SbC} 2$ & 16.72 & 86.37 & 24.12 & 77.36 & 654.79 & 0.22 & 14.89 \\
\hline $\mathrm{SbC} 3$ & 17.77 & 102.55 & 25.68 & 86.79 & 699.87 & 0.54 & 10.49 \\
\hline $\mathrm{SbC} 4$ & 18.27 & 112.37 & 27.33 & 88.27 & 262.98 & 0.56 & 13.85 \\
\hline Avg. & 16.69 & 106.05 & 26.26 & 80.62 & 534.43 & 0.39 & 13.04 \\
\hline \multirow{2}{*}{ Range } & $14.33-$ & $85.17-$ & $23.48-$ & 69.18- & 262.98- & $0.19-$ & $10.49-$ \\
\hline & 18.36 & 132.59 & 27.98 & 91.25 & 774.2 & 0.56 & 15.12 \\
\hline Background & $* * 1-40$ & $* * * 16$ & $* * 20-30$ & $* * 1-100$ & & $* * * 1.9$ & $* * 10-20$ \\
\hline$* * * *$ Erath crust & 10 to 12 & 20 & $25-75$ & $125-185$ & $260-730$ & $0.1-0.2$ & 15 \\
\hline **Alloway, 1990 & \multicolumn{3}{|l|}{ *Standard } & \multicolumn{4}{|c|}{ ******Kabata-Pendias and Mukherjee, 2007} \\
\hline
\end{tabular}

In general, the nickel concentration in subsurface soil samples is more than in surface samples, and this may be a result of the filtration processes. Where Beygi and Jalali (2018) indicated that some subsoil 
types have higher concentrations than the surface soil sample as a result of additions, losses, relocations, and shifts in soil horizons or rock impacts or both. The average copper $(\mathrm{Cu})$ concentration reached $25.23 \mathrm{ppm}$ in surface soil samples and 26.26ppm in subsurface samples, which is within the global concentrations according to Alloway (1990) and within its ranges in the rocks of the earth's crust according to Kabata-Pendias and Mukherjee, 2007). Between 20-30ppm and 25-75ppm respectively, (Tables 2 and (3) and Fig. 3. Although the copper concentration in most of the studied samples is within its global averages, its concentration in the surface sample (SC4) of (27.98ppm) and subsurface samples (SbB3, SbB4, SbB5) which are $(27.68,27.96,27.98 \mathrm{ppm})$, respectively Less than the selected standard soil sample (SA6) of (28.53ppm). Its concentration in subsurface samples (SbB4, SbB5) of (27.96 and $27.98 \mathrm{ppm})$, respectively, is slightly higher than the subsurface standard sample (SbA6) of (27.89ppm). And as (Morse et al., 2016) indicated that the concentrations of samples near the road and traffic movement are higher compared to the concentrations of other samples, and pollution with copper may be attributed to vehicle exhaust and waste, tire scraping and lubricating oils.

The average chromium $(\mathrm{Cr})$ concentration was $77.23 \mathrm{ppm}$ on the surface and $80.62 \mathrm{ppm}$ in the subsurface soil. It is within the global ranges of 1-100ppm) according to Alloway (1990), and less than the ranges of the rocks of the Earth's crust, which amount to $125-185 \mathrm{ppm}$ according to Kabata-Pendias and Mukherjee (2007) and as shown in (Tables 2 and 3 and Fig. 3. The average chromium concentration in the surface samples (SB4, SC4) with higher concentrations than the selected standard surface sample (SA6) of 85.77ppm and the subsurface (SbB4, SbB5) samples had higher than the Standard sample (SbA6) (90.36ppm). The interesting point is the all samples that have high chromium concentrations in the surface and subsurface soils are near to the traffic route. The average of Strontium ( $\mathrm{Sr}$ ) concentration in the surface soil samples are $497.85 \mathrm{ppm}$ and $534.43 \mathrm{ppm}$ in the subsurface soil. The concentration of strontium in all the studied samples located within the range of the Earth's crust, which is 260-730ppm according to Kabata-Pendias and Mukherjee (2007) with the exception of one sample (SbA2) of (774.20ppm). It may be caused by point pollution resulting from human activities such as burning local fields and dumping agriculture waste (Sun et al., 2010), while the average of cadmium in the surface $(0.38 \mathrm{ppm})$ and in the subsurface soil $(0.39 \mathrm{ppm})$. The concentration of cadmium in all the studied samples is lower than its global levels of (1.9 ppm) according to (Alloway, 2000) and more than the rates of its concentration in the earth's crust that ranges between (0.1-0.2ppm) (Kabata-Pendias and Mukherjee, 2007).

The cadmium concentration in all surface samples of the study area is higher than the standard surface sample (SA6) of (0.18ppm), and its concentration in most subsurface samples is higher than the standard subsurface sample (SbA6), the indicates the soil of the study area is affected by fertilization with phosphate fertilizers, in addition to the use of insecticides (Alkhader, 2015). Also (Harrison and Ward, 2001) mentioned that cadmium is emitted into the air through smelters, and factories, as combustion products increase the concentration of cadmium in the atmosphere and then deposit it in the soil. And that the elements that originate from natural sources are relatively low, while the elements affected by human sources are very high (Baran et al., 2018). The cadmium is relatively soluble and bound to the soil surface, and the distribution pattern may reflect the potential downturn of the elements through rain infiltration (Wong et al., 2006). Mixed pollutants are often affected on the surface soil because of irrigation or rain when high concentrations of it in surface and subsurface samples are almost egalitarian (Shehzad et al., 2019). The average concentration of lead $(\mathrm{Pb})$ was $13.26 \mathrm{ppm}$ in the surface sample and $13.04 \mathrm{ppm}$ in subsurface soil samples. It is observed that the concentration of lead in the samples under study is within the range of its global concentrations according to (Alloway, 1990) and less than its concentration rates in the earth's crust according to Kabata-Pendias and Mukherjee (2007) and 10-20ppm and $15 \mathrm{ppm}$ respectively. This indicates that the human input for this component is relatively low (Tables 2 and 3) (Fig.3). 

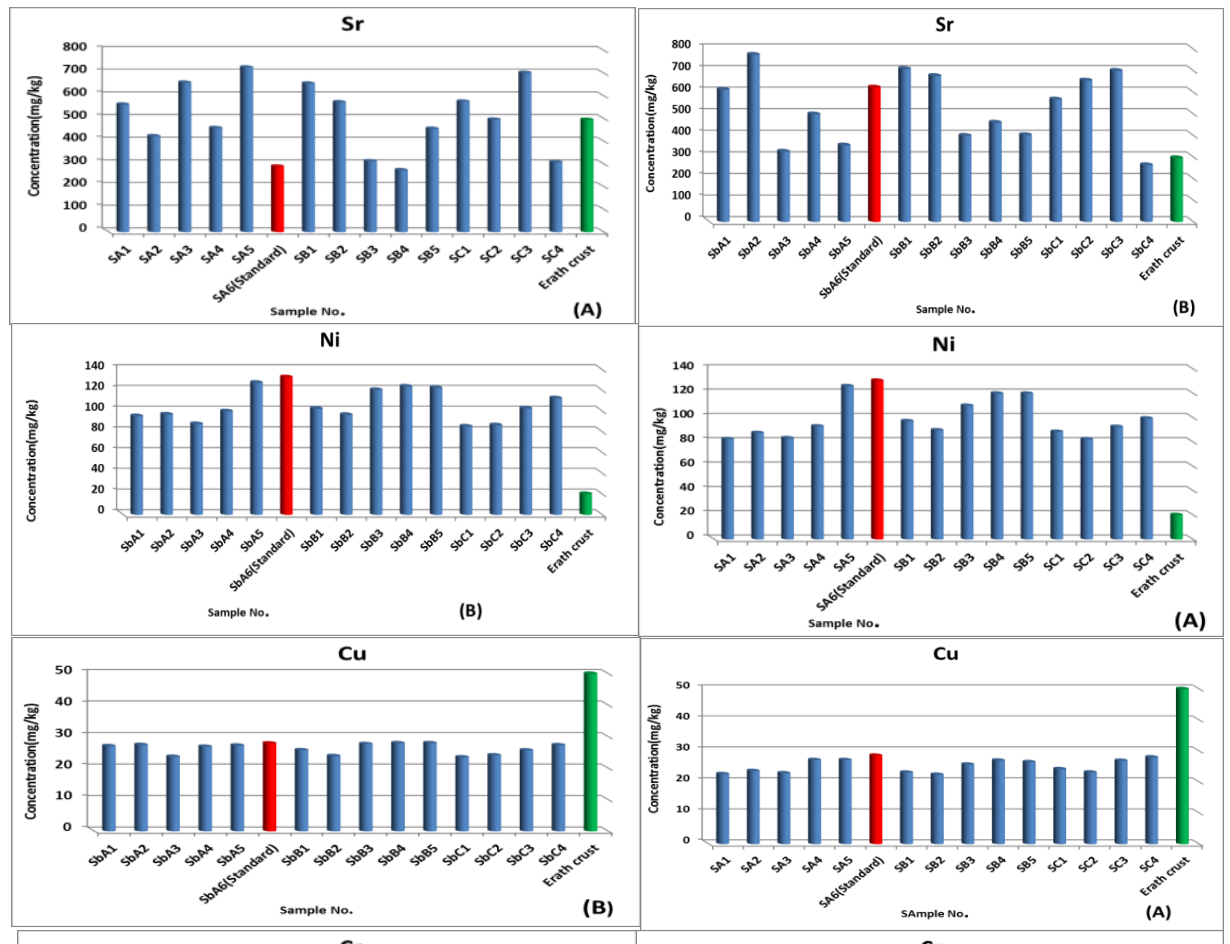

(B)

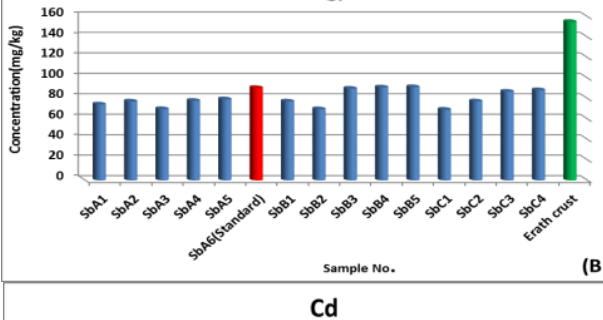

(B)
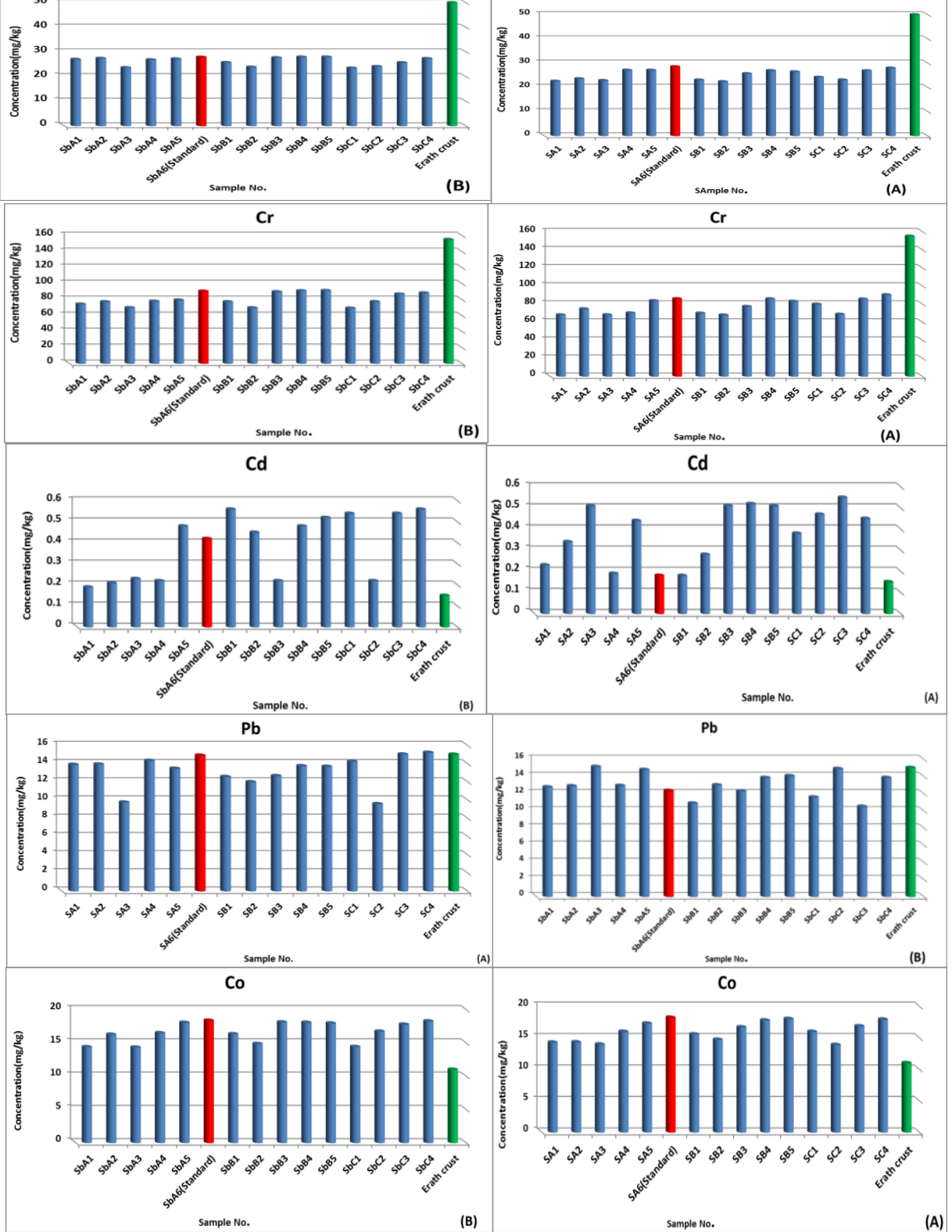

Fig.3. Concentrations of heavy elements (A) for surface soil and (B) for subsurface soils in the study samples comparison with (Kabata-Pendias and Mukherjee, 2007) 
It was observed that the concentration of lead in most surface samples was less than its concentration in the selected surface standard sample (SA6), which was $14.89 \mathrm{ppm}$ with the exception of two samples (SC3, SC4) of $(15.02,15.21 \mathrm{ppm})$ respectively. While it is observed that the lead concentration in most subsurface samples is more than the standard subsurface sample (SbA6) of (12.33ppm) except for the samples ( $\mathrm{SbB} 1, \mathrm{SbC} 1, \mathrm{SbC} 3)$. The increase in lead concentration in some soil samples may be due to its proximity to traffic routes and the effect of car exhaust, which is a cause of lead contamination of the soil (Kimbrough and Krouskas, 2012; Shehzad et al., 2019).

Most of the heavy elements have a strong significant relationship between them. The relationship between $\mathrm{Co}$ and $\mathrm{Ni}(\mathrm{r}=0.85, \mathrm{r}=0.83 ; \mathrm{n}=15), \mathrm{Cu}(\mathrm{r}=0.90, \mathrm{r}=0.71 ; \mathrm{n}=15)$ and $\mathrm{Cr}(0.89, \mathrm{r}=0.92 ; \mathrm{n}=15)$ for the surface and subsurface soil samples respectively are statistically a strong positive significant. As well as the Co relates with lead $(\mathrm{Pb})$ in the surface soil with a strong positive relationship $(\mathrm{r}=0.66$; $\mathrm{n}=15)$. As well, Ni has a strong positive correlation with $\mathrm{Cu}(\mathrm{r}=0.74, \mathrm{r}=0.80 ; \mathrm{n}=15)$ and $(\mathrm{Cr})(\mathrm{r}=0.68$, $r=0.82 ; n=15)$ for both surface and subsurface soil samples respectively. It is also observed in the surface soil sample that the $\mathrm{Cu}$ correlates with $\mathrm{Cr}(0.84 ; \mathrm{n}=15)$ and $\mathrm{Pb}(0.66 ; \mathrm{n}=15)$, and $\mathrm{Cr}$ with $\mathrm{Pb}(\mathrm{r}=$ $0.67 ; n=15)$ has a positive significant relationship. It is observed a positive significant relationship between $\mathrm{Cu}$ and $\mathrm{Cr}(\mathrm{r}=0.78 ; \mathrm{n}=15)$ in the subsurface soil, which indicates the common sources prepared for heavy elements in the soil of the study area, as (Al-Dabbas and Abdullah 2020) indicated that the mafic rocks are enrichment with $\mathrm{Co} \mathrm{Pb}, \mathrm{Cu}$. Daniel et al. (2019) found that transitional trace elements often show a positive association with each other. This may indicate that the source of the heavy elements in soil mainly comes from Factories activities (Ding et al., 2018). Or it may be the result of the affinity and geochemical association between the elements $(\mathrm{Co}, \mathrm{Cr}, \mathrm{Cu}$ and $\mathrm{Pb})$ due to their possession of Chalcophilic properties (Goldschmidt, 1958). Also, the strong relationship between heavy elements in the soil of the study area indicates the similarity in behavior and geochemical properties such as ionic size and radius (Daniel et al., 2019) among them, such as the convergence of the ionic radius of Ni ( 0.69 $\mathrm{A}^{\circ}$ ) with the ionic radius of Co $\left(0.72 \mathrm{~A}^{\circ}\right)$ (Goldschmidt, 1958; Al-Jubouri, 1972).

It has been observed that most of the heavy elements in the surface soil sample have a strong positive correlation with iron oxide $\left(\mathrm{Fe}_{2} \mathrm{O}_{3}\right)$. This may be due to its adsorption on clay mineral surfaces or due to its association with iron oxides and hydroxides. It was also observed that the Sr correlated with a positive and strong significant relationship with $\mathrm{CaO}(\mathrm{r}=0.87, \mathrm{r}=0.85 ; \mathrm{n}=15), \mathrm{CaCO}_{3}(\mathrm{r}=0.71, \mathrm{r}=$ $0.55 ; \mathrm{n}=15$ ) and a positive relationship with $\mathrm{SO}_{3}$ and $\mathrm{CaSO}_{4} \cdot 2 \mathrm{H}_{2} \mathrm{O}$ in the surface and subsurface horizon of the soil respectively, which indicates the enrichment of limestone rocks with the Sr compared to silicate rocks, as they spread within a region The study detects limestone to form the hatch. This may be attributed to their co-occurrence in the mineral plagioclase (Wu et al., 2014). Calcium and strontium originate mainly from limestone, and differences in the concentration of trace elements in the fine fractions depend on the presence of $\mathrm{CaSO}_{4} \cdot 2 \mathrm{H}_{2} \mathrm{O}$ (Pavlin et al., 2018).

No significant relationship of cadmium $(\mathrm{Cd})$ with heavy elements was observed in the different regions of the surface and subsurface soil sample, while a negative correlation of $\mathrm{Cd}$ with $\mathrm{SO}_{3}(\mathrm{r}=-0.31$, $\mathrm{r}=-0.61 ; \mathrm{n}=15)$ and $\mathrm{CaSO}_{4} \cdot 2 \mathrm{H}_{2} \mathrm{O}(\mathrm{r}=-0.51, \mathrm{r}=-0.56 ; \mathrm{n}=15)$ respectively was observed, which indicates that the $\mathrm{Cd}$ is not affected by soil salinity and the natural sources of gypsum spread in the study area. It also indicates the difference in prepared sources of $(\mathrm{Cd})$ and sulfur oxide $\left(\mathrm{SO}_{3}\right)$ in the studied area.

\subsection{Soil Pollution by Heavy Metals}

To assess the amount of pollution and the extent of the richness of the surface and subsurface soil with heavy elements in the study area, confirmed methods and indicators have been applied to determine the extent of its contamination with these elements as follows: 


\subsubsection{Geo accumulation index (Igeo)}

The geo accumulation factor allows the evaluation of elemental contamination in soil samples, and is used to predict (estimate) environmental risks for specific areas (Haris, 2017), and are calculated using the following equation (Muller, 1969):

$$
\mathrm{I}_{\text {geo }}=\log _{2} \frac{\mathrm{C}_{\mathrm{n}}}{1.5 \times \mathrm{B}_{\mathrm{n}}}
$$

Where $C_{n}$ is the concentration of trace elements in the surface and subsurface soil in units (ppm), and $\mathrm{B}_{\mathrm{n}}$ is the reference concentration of the element representing its content in the earth's crust according to (Wedepohl, 1995), and a constant value (1.5) is used for possible changes in the reference data due to rocky influences (lithogenic), and the geo accumulation factor (Igeo) in the soil is classified according to (Muller, 1969; Salman et al., 2019), and as shown in Table 4.

Table 4. Categories of soil pollution according to the values of the geo accumulation factor (Igeo) after (Muller, 1969; Salman et al., 2019).

\begin{tabular}{lc}
\hline Value & Environmental Risk Grade \\
\hline $\mathrm{I}_{\text {geo }} \leq 0$ & Practically uncontaminated \\
$0<\mathrm{I}_{\text {geo }} \leq 1$ & Uncontaminated to moderately contaminated \\
$1<\mathrm{I}_{\text {geo }} \leq 2$ & Moderately contaminated \\
$2<\mathrm{I}_{\text {geo }} \leq 3$ & Moderately to heavily contaminated \\
$3<\mathrm{I}_{\text {geo }} \leq 4$ & Heavily contaminated \\
$4<\mathrm{I}_{\text {geo }} \leq 5$ & Heavily to extremely contaminated \\
$\mathrm{I}_{\text {geo }}>5$ & Extremely contaminated \\
\hline
\end{tabular}

It was found through the calculation of the geo accumulation factor that the surface and subsurface soil rates for heavy elements were in the following descending order: $\mathrm{Cd}>\mathrm{Ni}>\mathrm{Sr}>\mathrm{Cu}>\mathrm{Pb}>\mathrm{Co}>\mathrm{Cr}$, as in Tables 5 and 6 and Figs. 4 and 5. that the geo accumulation factor in the surface soil with $\mathrm{Co}, \mathrm{Ni}, \mathrm{Cu}$, $\mathrm{Cr}, \mathrm{Sr}$ and $\mathrm{Pb}$ in all samples of the study area and with the $\mathrm{Cd}$ in some samples, including the standard sample (SA6) was Uncontaminated to moderately contaminated as shown in Table 4 while the samples (SA3, SB3, SB4, SB5, SC3) for cadmium were moderately contaminated.

The geo accumulation factor in the subsurface soil with elements of $\mathrm{Co}, \mathrm{Ni}, \mathrm{Cu}, \mathrm{Cr}, \mathrm{Sr}, \mathrm{Pb}$ in all samples, the study area, and with the $\mathrm{Cd}$ in some samples, including the standard sample (SA6), were Uncontaminated to moderately contaminated) as shown in Table 4 while with $\mathrm{Cd}$ in the samples (SbB1, $\mathrm{SbB} 5, \mathrm{SbC} 1, \mathrm{SbC} 35, \mathrm{SbC} 4)$ they were moderately contaminated.

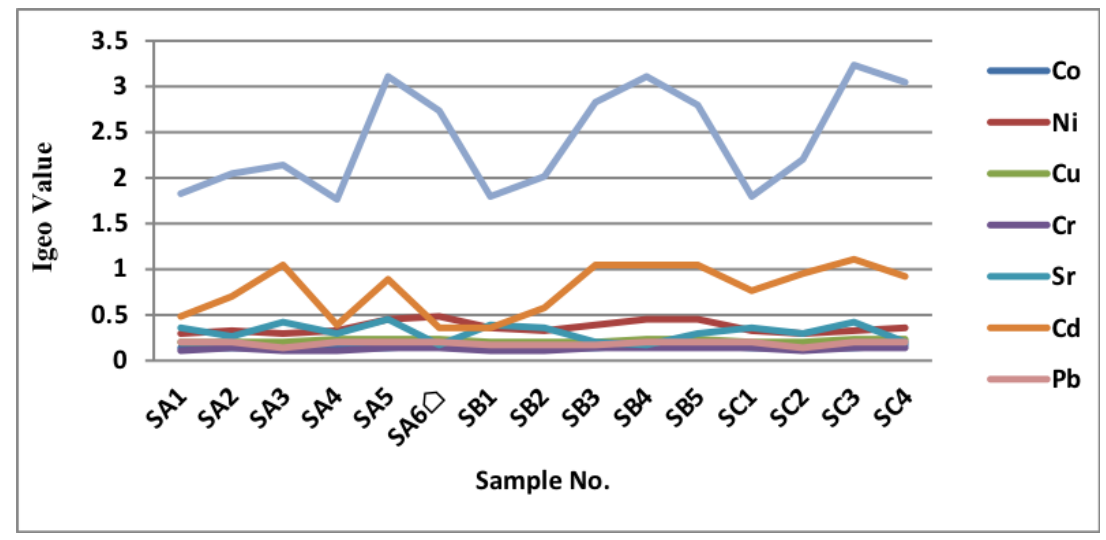

Fig.4. Evaluation of the trace elements in the surface soil of the study area according to the geo accumulation factor (Igeo) 
Table 5. Results pollution assessment of geo accumulation factor for surface soil samples

\begin{tabular}{lccccccc}
\hline Sample No. & Co & Ni & $\mathbf{C u}$ & $\mathbf{C r}$ & $\mathbf{S r}$ & $\mathbf{C d}$ & $\mathbf{P b}$ \\
\hline SA1 & 0.12 & 0.29 & 0.18 & 0.11 & 0.34 & 0.46 & 0.19 \\
SA2 & 0.12 & 0.31 & 0.19 & 0.12 & 0.25 & 0.68 & 0.19 \\
SA3 & 0.12 & 0.30 & 0.18 & 0.11 & 0.40 & 1.02 & 0.13 \\
SA4 & 0.13 & 0.33 & 0.22 & 0.11 & 0.28 & 0.38 & 0.19 \\
SA5 & 0.14 & 0.45 & 0.22 & 0.13 & 0.44 & 0.88 & 0.18 \\
SA6॰ & 0.15 & 0.47 & 0.23 & 0.14 & 0.17 & 0.36 & 0.20 \\
SB1 & 0.13 & 0.35 & 0.18 & 0.11 & 0.39 & 0.36 & 0.17 \\
SB2 & 0.12 & 0.32 & 0.18 & 0.11 & 0.34 & 0.56 & 0.16 \\
SB3 & 0.14 & 0.39 & 0.21 & 0.12 & 0.19 & 1.02 & 0.17 \\
SB4 & 0.15 & 0.43 & 0.22 & 0.14 & 0.16 & 1.04 & 0.19 \\
SB5 & 0.15 & 0.43 & 0.21 & 0.13 & 0.27 & 1.02 & 0.18 \\
SC1 & 0.13 & 0.32 & 0.19 & 0.13 & 0.35 & 0.76 & 0.19 \\
SC2 & 0.12 & 0.29 & 0.18 & 0.11 & 0.30 & 0.94 & 0.13 \\
SC3 & 0.14 & 0.33 & 0.21 & 0.14 & 0.42 & 1.10 & 0.20 \\
SC4 & 0.15 & 0.36 & 0.22 & 0.14 & 0.18 & 0.90 & 0.21 \\
Avg. & 0.13 & 0.36 & 0.20 & 0.12 & 0.30 & 0.77 & 0.18 \\
\hline
\end{tabular}

Table 6. Results pollution assessment of geo accumulation factor for sub surface soil samples

\begin{tabular}{lccccccc}
\hline Sample & Co & Ni & Cu & Cr & Sr & Cd & Pb \\
\hline SbA1 & 0.12 & 0.34 & 0.22 & 0.12 & 0.37 & 0.38 & 0.17 \\
SbA2 & 0.13 & 0.35 & 0.22 & 0.12 & 0.47 & 0.42 & 0.17 \\
SbA3 & 0.12 & 0.31 & 0.19 & 0.11 & 0.20 & 0.46 & 0.20 \\
SbA4 & 0.14 & 0.36 & 0.21 & 0.12 & 0.30 & 0.44 & 0.17 \\
SbA5 & 0.15 & 0.46 & 0.22 & 0.13 & 0.21 & 0.96 & 0.20 \\
SbA6 & 0.15 & 0.47 & 0.22 & 0.14 & 0.37 & 0.84 & 0.17 \\
SbB1 & 0.14 & 0.37 & 0.21 & 0.12 & 0.43 & 1.12 & 0.15 \\
SbB2 & 0.12 & 0.34 & 0.19 & 0.11 & 0.41 & 0.90 & 0.18 \\
SbB3 & 0.15 & 0.43 & 0.22 & 0.14 & 0.24 & 0.44 & 0.17 \\
SbB4 & 0.15 & 0.44 & 0.22 & 0.14 & 0.28 & 0.96 & 0.19 \\
SbB5 & 0.15 & 0.44 & 0.22 & 0.14 & 0.24 & 1.04 & 0.19 \\
SbC1 & 0.12 & 0.30 & 0.19 & 0.11 & 0.34 & 1.08 & 0.16 \\
SbC2 & 0.14 & 0.31 & 0.19 & 0.12 & 0.39 & 0.44 & 0.20 \\
SbC3 & 0.15 & 0.37 & 0.21 & 0.14 & 0.42 & 1.08 & 0.14 \\
SbC4 & 0.15 & 0.40 & 0.22 & 0.14 & 0.16 & 1.12 & 0.19 \\
Avg. & 0.14 & 0.38 & 0.21 & 0.13 & 0.32 & 0.78 & 0.18 \\
\hline
\end{tabular}

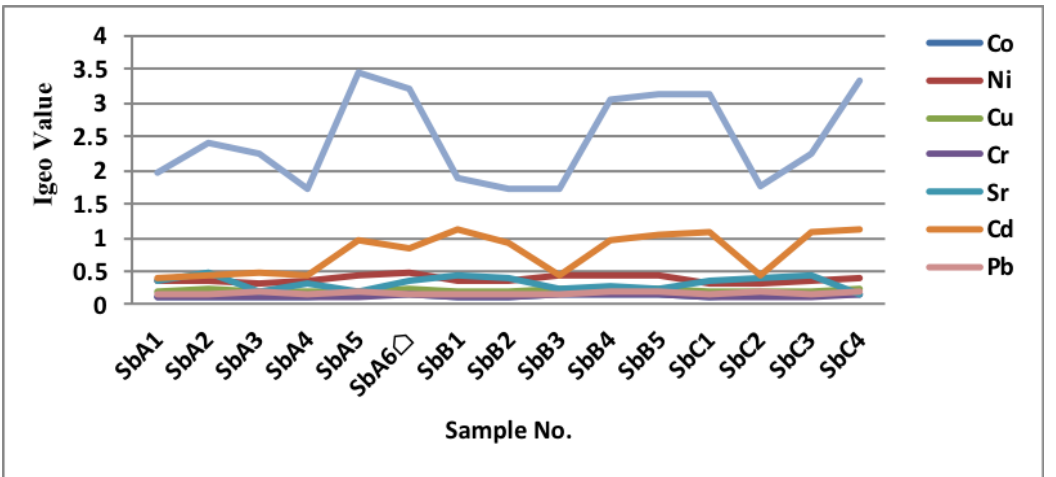

Fig.5. Evaluation of the trace elements in the sub surface soil of the study area according to the geo accumulation factor (Igeo) 


\subsubsection{Potential ecological risk factor (Er) and risk index (RI)}

The potential environmental risk indicator is used to assess soil contamination with trace elements (Liu et al., 2017). It represents the sum of the environmental risk factor for one component in the sample (Hakanson, 1980). To calculate the indicators of potential environmental hazards of the elements, the rates were used suggested by (Hakanson, 1980).

$$
\begin{gathered}
C_{f}^{i}=\frac{C_{s}^{i}}{C_{R}^{i}} \\
E r^{i}=\operatorname{Tr}^{i} * C_{f}^{i} \\
R I=\sum_{i=1}^{s} E r^{i}
\end{gathered}
$$

Where $C_{f}^{i}$ is the pollution factor for the trace elements, $C_{s}^{i}$ is the value of the measured concentrations of the elements in the soil, $C_{R}^{i}$ is the basic reference values for the trace elements in the earth's crust according to (Wedephol, 1995; Newaz et al., 2021). And that $E r^{i}$ is the environmental hazard index of a specific element, $\operatorname{Tr}^{i}$ is the toxic response factor proposed by (Hakanson, 1980), and (Liu et al., 2017) indicated that the value of $E r^{i}$ is equal to $(\mathrm{Cd}=30, \mathrm{Cr}=2, \mathrm{Cu}$ and $\mathrm{Pb}=5, \mathrm{Ni}=5)$ and for the elements $(\mathrm{Co}=1, \mathrm{Sr}=6)$ ( $\mathrm{Li}$ et al., 2018), and the RI represents the overall potential risk index for the elements (Liu et al., 2017). They were classified according to (Hakanson, 1980) (Table 7).

Table 7. Classification of the environmental risk factor and the potential environmental risk index of the elements

\begin{tabular}{cccc}
\hline$E r^{i}$ & Pollution Degree & RI & Risk Degree \\
\hline$E r^{i}<40$ & Low potential ecological risk & $\mathrm{RI}<150$ & Low ecological risk \\
$40 \leq E r^{i}<80$ & Moderate potential ecological & $150 \leq \mathrm{RI}<300$ & Moderate ecological risk \\
& risk & & Considerable ecological \\
$80 \leq E r^{i}<160$ & Considerable potential ecological & $300 \leq \mathrm{RI}<600$ & risk \\
$160 \leq E r^{i}<320$ & risk & RI $\geq 300$ & Very strong \\
$E r^{i} \geq 320$ & Extremely potential ecological \\
& high & & \\
\hline
\end{tabular}

It was found through the calculation of the potential environmental risk factor that the rates of the environmental risk factor in the surface and subsurface soils of the heavy elements was: $\mathrm{Cd}>\mathrm{Sr}>\mathrm{Ni}>$ $\mathrm{Cu}>\mathrm{Pb}>\mathrm{Cr}>\mathrm{Co}$ as in Tables 8 and 9, Figs. 6 and 7 and that the environmental risk of the surface soil with elements ( $\mathrm{Co}, \mathrm{Ni}, \mathrm{Co}, \mathrm{Cr}, \mathrm{Sr}$ and $\mathrm{Pb})$ in all samples was low potential ecological risk and for the cadmium in the samples (SA1, SA4 SA6, SB1) was moderate potential ecological risk and in the rest of the samples, with the exception of the sample (SC3), were Considerable potential ecological risk with values more than the adopted standard sample (SbA6) and in the sample (SC3) for which the environmental risk was high potential ecological risk which amounted to 165 .

The environmental risk of the subsurface soil with elements $(\mathrm{Co}, \mathrm{Ni}, \mathrm{Cu}, \mathrm{Co}, \mathrm{Sr}$ and $\mathrm{Pb}$ ) in all samples was low potential ecological risk and for $\mathrm{Cd}$ in the samples (SbA1, SbA2, SbA3, SbA4 SbB3, $\mathrm{SbC2}$ ) was of moderate potential ecological Risk with values less than the standard sample ( $\mathrm{SbA6}$ ), and in the samples (SbA5, SbB2, SbB4, SbB5) were of significant considerable potential ecological risk 
including the standard sample (SbA6), and in the samples (SbB1, SbC1, SbC3, SbC4), the potential environmental risk index was high potential ecological risk. The $\mathrm{Cd}$ concentrations in the soil of the study area were more than its average in the earth's crust (Kabata-Pendias and Mukherjee, 2007), and it may be attributed to its high toxicity level, reaching 30 according to Hakanson (1980). Or it may also bind to the high movement of $\mathrm{Cd}$ in the soil and be leached to the subsurface layers (Wieczorek et al., 2018). Al-Hamdani et al., (2016) explained that the considerable amount of Cd is mainly binding to the organic matter and carbonate in the differnet horizon of soil.

Table 8. The values of the environmental risk factor and the potential environmental risk index of the trace elements in the surface soil of the study area.

\begin{tabular}{ccccccccc}
\hline Sample & & & & Er & & & RI \\
\hline & Co & $\mathrm{Ni}$ & $\mathrm{Cu}$ & $\mathrm{Cr}$ & $\mathrm{Sr}$ & $\mathrm{Cd}$ & $\mathrm{Pb}$ & \\
SA1 & 0.59 & 7.36 & 4.52 & 1.08 & 10.13 & 69 & 4.69 & 98.06 \\
SA2 & 0.6 & 7.81 & 4.72 & 1.18 & 7.62 & 102 & 4.7 & 129.41 \\
SA3 & 0.58 & 7.42 & 4.57 & 1.08 & 11.87 & 153 & 3.29 & 182.62 \\
SA4 & 0.67 & 8.29 & 5.42 & 1.11 & 8.27 & 57 & 4.84 & 86.27 \\
SA5 & 0.72 & 11.24 & 5.42 & 1.33 & 13.07 & 132 & 4.55 & 169.52 \\
SA6 & 0.76 & 11.65 & 5.71 & 1.36 & 5.21 & 54 & 5.03 & 84.76 \\
SB1 & 0.65 & 8.68 & 4.62 & 1.11 & 11.79 & 54 & 4.24 & 85.77 \\
SB2 & 0.61 & 8.01 & 4.78 & 1.08 & 10.31 & 84 & 4.05 & 113.61 \\
SB3 & 0.69 & 9.8 & 5.13 & 1.23 & 5.63 & 153 & 4.27 & 180.83 \\
SB4 & 0.74 & 10.7 & 5.39 & 1.36 & 4.92 & 156 & 4.64 & 184.94 \\
SB5 & 0.75 & 10.69 & $5 . .29$ & 1.32 & 8.21 & 153 & 4.62 & 179.66 \\
SC1 & 0.66 & 7.89 & 4.84 & 1.27 & 10.37 & 114 & 4.8 & 144.51 \\
SC2 & 0.58 & 7.35 & 4.62 & 1.09 & 8.93 & 141 & 3.23 & 167.64 \\
SC3 & 0.71 & 8.25 & 5.38 & 1.36 & 12.65 & 165 & 5.07 & 199.65 \\
SC4 & 0.75 & 8.87 & 5.59 & 1.43 & 5.55 & 135 & 5.14 & 163.49 \\
Avg. & 0.67 & 8.93 & 5.05 & 1.23 & 8.97 & 114.8 & 4.48 & 144.72 \\
\hline
\end{tabular}

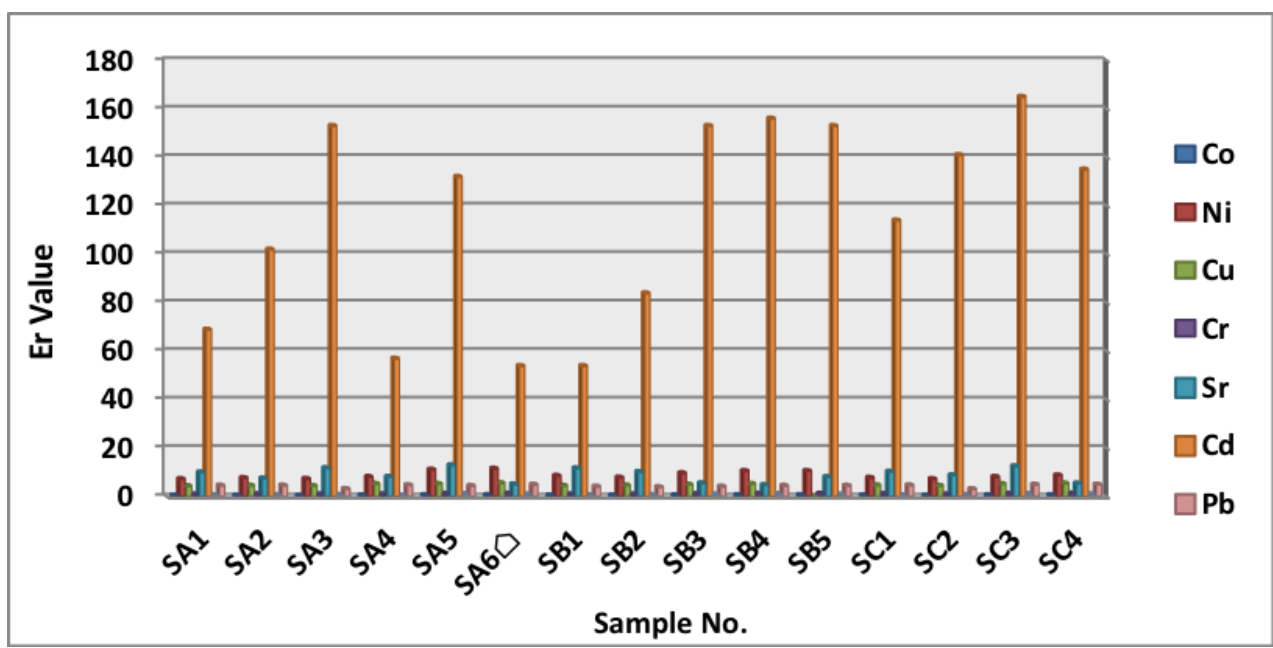

Fig.6. Evaluation of the trace elements with the potential environmental risk factor of the trace elements in the surface soil of the study area 
Table 9. The values of the environmental risk factor and the potential environmental risk index of the trace elements in the subsurface soil for the study area

\begin{tabular}{ccccccccc}
\hline Sample & & & & $\mathbf{E r}$ & & & RI \\
\hline & $\mathbf{C o}$ & $\mathbf{N i}$ & $\mathbf{C u}$ & $\mathbf{C r}$ & $\mathbf{S r}$ & $\mathbf{C d}$ & $\mathbf{P b}$ & \\
$\mathrm{SbA} 1$ & 0.59 & 8.49 & 5.41 & 1.18 & 11.03 & 57 & 4.31 & 88.7 \\
$\mathrm{SbA2}$ & 0.59 & 8.63 & 5.484 & 1.23 & 13.95 & 63 & 4.35 & 98.014 \\
$\mathrm{SbA3}$ & 0.58 & 7.81 & 4.732 & 1.11 & 5.86 & 69 & 5.11 & 95.012 \\
$\mathrm{SbA4}$ & 0.67 & 8.91 & 5.37 & 1.24 & 8.98 & 66 & 4.36 & 96.2 \\
$\mathrm{SbA5}$ & 0.72 & 11.37 & 5.44 & 1.26 & 6.38 & 144 & 4.99 & 175.35 \\
$\mathrm{SbA6}$ & 0.76 & 11.84 & 5.58 & 1.43 & 11.21 & 126 & 4.16 & 162.02 \\
$\mathrm{SbB} 1$ & 0.65 & 9.14 & 5.15 & 1.22 & 12.76 & 168 & 3.67 & 201.27 \\
$\mathrm{SbB} 2$ & 0.61 & 8.61 & 4.77 & 1.1 & 12.18 & 135 & 4.39 & 167.43 \\
$\mathrm{SbB} 3$ & 0.69 & 10.75 & 5.54 & 1.42 & 7.18 & 66 & 4.15 & 96.81 \\
$\mathrm{SbB} 4$ & 0.74 & 11.05 & 5.59 & 1.44 & 8.28 & 144 & 4.68 & 176.97 \\
$\mathrm{SbB} 5$ & 0.75 & 10.92 & 5.59 & 1.45 & 7.24 & 156 & 4.75 & 187.77 \\
$\mathrm{SbC1}$ & 0.66 & 7.61 & 4.69 & 1.09 & 10.21 & 162 & 3.91 & 190.85 \\
$\mathrm{SbC} 2$ & 0.58 & 7.71 & 4.82 & 1.23 & 11.79 & 66 & 5.03 & 98 \\
$\mathrm{SbC3}$ & 0.71 & 9.16 & 5.14 & 1.38 & 12.61 & 162 & 3.54 & 195.77 \\
$\mathrm{SbC} 4$ & 0.75 & 10.03 & 5.47 & 1.41 & 4.74 & 168 & 4.68 & 196.24 \\
$\mathrm{Avg}$. & 0.67 & 9.47 & 5.25 & 1.28 & 9.63 & 116.8 & 4.41 & 148.43 \\
\hline
\end{tabular}

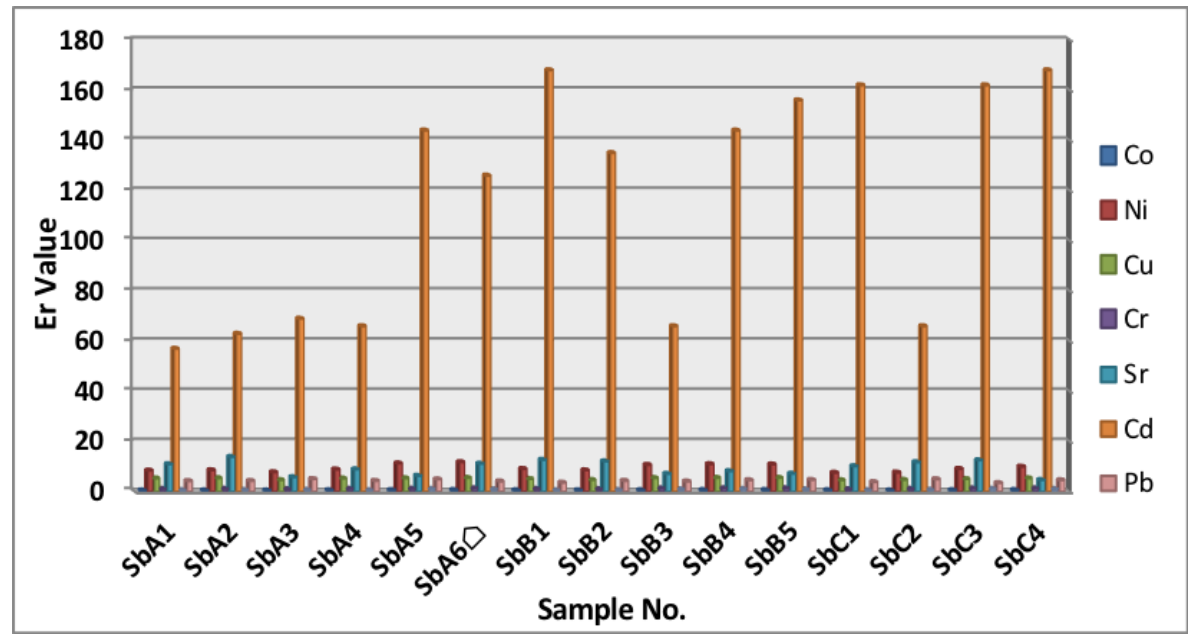

Fig.7. Evaluation of the trace elements with the potential environmental risk factor of the trace elements in the subsurface soil of the study area

By observing the RI values, it was found that the heavy elements in the surface soil sample of the study area in the samples (SA1, SA2, SA4, SB1, SB2, SC1) were of low ecological risk, including the standard sample (SA6). And in the remainder of the samples, it had a moderate ecological risk, that is, with values more than the standard sample (SA6) (Table 8) and (Fig. 8A).

The values of the potential environmental risk index showed that the heavy elements in the subsurface soil of the study area for the samples (SbA1, SbA2, SbA3, SbA4, SbB3, SbC2) were of low ecological risk, with values more than the standard sample (SbA6). The remainder of the samples had (Moderate ecological risk), including the standard sample (SbA6) (Table 9) and (Fig. 8B). 

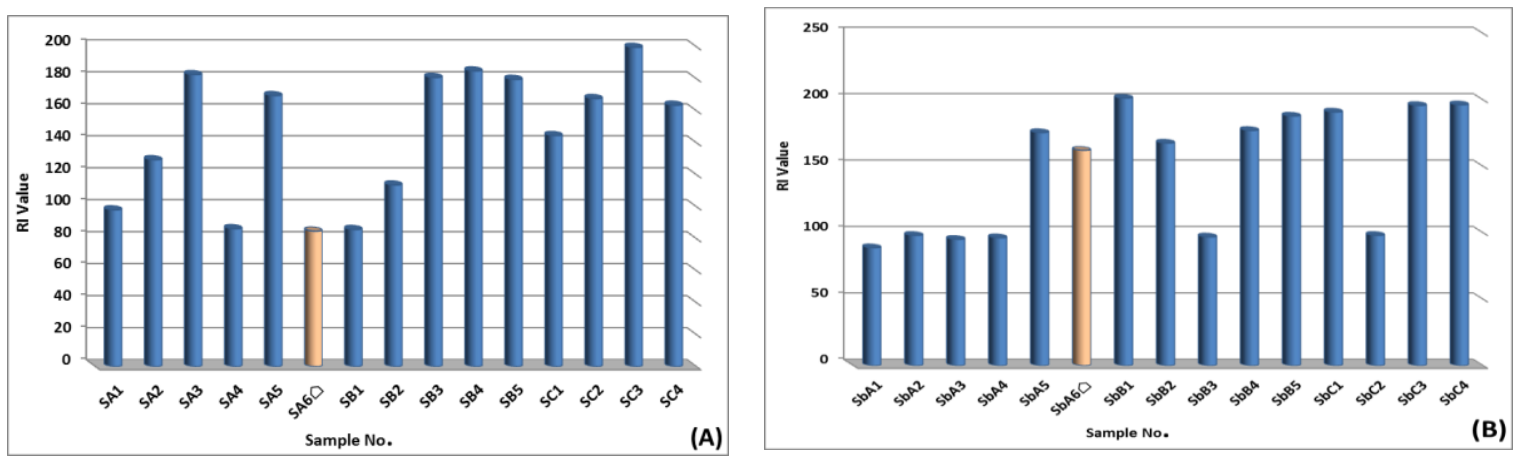

Fig.8. Evaluation of the indicator of potential environmental risks with heavy elements in (A) the surface soil sample and (B) in the subsurface soil of the study area.

\section{Conclusions}

It is apparent through the results of the geochemical analysis that the relative content of the concentration of trace elements in the surface and subsurface soil is in the following descending order: $(\mathrm{Sr}>\mathrm{Ni}>\mathrm{Cr}>\mathrm{Cu}>\mathrm{Co}>\mathrm{Pb}>\mathrm{Cd})$, and that the concentration of the elements $(\mathrm{Co}, \mathrm{Ni}, \mathrm{Cu}, \mathrm{Cr}, \mathrm{Sr})$ in subsurface soils is more than surface soil sample, may be attributed to the effect of weathering and washing processes of the surface soil sample components and their concentration in the deep subsurface horizons of the soil by the effect of accumulation or depletion processes.

The concentrations of heavy elements $(\mathrm{Co}, \mathrm{Ni}, \mathrm{Cd})$ is more than their normal rates when compared to the natural abundance of these elements in the earth's crust, which indicates the role of oil installations near the study area in increasing the soil content of these elements, as they contain its outputs are at high concentrations of some heavy elements, is located near the highway, which witnesses a large movement of transport means, as the fuel combustion products in the transport means contain high concentrations of some of these heavy elements. The observed correlation coefficients indicate the presence of a strong positive relationship between the elements $(\mathrm{Co}, \mathrm{Ni}, \mathrm{Cu}, \mathrm{Cr}, \mathrm{Pb}, \mathrm{Cd})$, which indicates the similarity in the source rocks prepared for these elements as well as the similarity in the geochemical behavior and the ionic radius to them, as well as the presence of a significant correlation for these elements with iron oxide $\left(\mathrm{Fe}_{2} \mathrm{O}_{3}\right)$, which indicates their association in geochemical environments, and the occurrence of the process of adsorption or substitution of the element replacing iron in the minerals of weathering residues, as well as agricultural fertilizers as common sources in increasing the concentration of trace elements in the soil of the study area.

The $\mathrm{Sr}$ is associated with a positive and strong significant relationship with $\mathrm{CaO}$ and $\mathrm{CaCO}_{3}$ and a positive relationship with $\mathrm{SO}_{3}, \mathrm{CaSO}_{4} \cdot 2 \mathrm{H}_{2} \mathrm{O}$ in the different areas of the soil, which indicates that the limestone rocks are enriched with the strontium element compared to silicate rocks. Where the croups out of Limestone within the Fatha Formation spreads to the studied area. This may be attributed to the presence of both in the plagioclase. And that the elements calcium and strontium originate mainly from limestone, and differences in the concentration of trace elements in the fine fractions depend on the presence of $\mathrm{CaSO}_{4} \cdot 2 \mathrm{H}_{2} \mathrm{O}$. There was no significant correlation of cadmium with most of the heavy elements in the different soil areas, while a negative correlation of cadmium was observed with $\mathrm{SO}_{3}$, $\mathrm{CaSO}_{4} \cdot 2 \mathrm{H}_{2} \mathrm{O}$ which indicates that $\mathrm{Cd}$ is not affected by soil salinity and natural sources of gypsum. Scattered in the study area. The difference also indicates the prepared sources of $\mathrm{Cd}$ and sulfur oxide $\mathrm{SO}_{3}$ in the study area.

The values of the geo accumulation factor in the different areas of the soil indicate that it is uncontaminated to moderately contaminated with $\mathrm{Co}, \mathrm{Ni}, \mathrm{Cu}, \mathrm{Cr}, \mathrm{Sr}, \mathrm{Pb}$ and that most soil samples are moderately contaminated with $\mathrm{Cd}$. 
The values of the potential environmental risk factor $(\mathrm{Er})$ for most of the elements $(\mathrm{Co}, \mathrm{Ni}, \mathrm{Cu}, \mathrm{Cr}$, $\mathrm{Sr}, \mathrm{Zn}, \mathrm{Pb}$ ) in the surface and subsurface soil area indicated that they are low potential ecological risk and that $\mathrm{Cd}$ poses an environmental risk considerable potential ecological risk to high potential ecological risk. It was found through the values of the potential environmental risk index (RI) in the surface soil of the study area in the samples near to gypsum quarries that they have a (low ecological risk), including the standard sample (SA6), and in the remainder of the samples they have moderate ecological risk. While in subsurface soils, the sample showed (SbA6) with Moderate ecological risk.

\section{Acknowledgements}

The authors would like to thank Prof. Dr. Yusuf K. Kadioğlu for his help during laboratory analysis which was carried out in the Ankara University, Earth Science Research and Application Center (YEBIM), Turkey. Also, thanks Azadi teaching hospital staff for their help with samples and their processing. The authors are very grateful to the Editor in Chief Prof. Dr. Salih M. Awadh, the Secretary of Journal Mr. Samir R. Hijab and the Technical Editors for their great efforts and valuable comments.

\section{References}

Al-Chalabi, A. S., and Hawker, D., 1997. Response of vehicular lead to the presence of street dust in the atmospheric environment of major roads. The Science of the Total Environment, 206, 195-202.

Al-Dabbas, M. A., and Abdullah, M. A., 2020. Assessment of soil pollution in the Ishaqi Project Area- Salah Al-Dean Governorate, Iraq. Iraqi Journal of Science, 61 (2), 382-388.

Al-Hamdani J.A., Awadh S. M., and Ibrahim O. S., 2016. Geochemical partitioning of heavy metals in the urban soil, Kirkuk, Iraq. Iraqi Geological Journal, 39-49 (1), 1-24 .

Al-Jubouri, Z.A., 1972. Geochemistry, origin and diagenesis of some Triassic gypsum deposits and associated sediments in the East Midlands. Unpublished Ph.D Thesis, University of Nottigham.

Al-Jumaily H.A.A., and Hasseb, D.N., 2021. impact of oxides and physiochemical properties of agricultural soil on bioaccumulation of toxic heavy elements in Wheat Grains in Yaychi, Northeast of Iraq. Iraqi Geological Journal, 54(1B), 69-78.

AlKhader, A. M. F., 2015. The impact of phosphorus fertilizers on heavy metals content of soils and vegetables grown on selected farms in Jordan. Agrotechnology, 4, 137.

Al-Obeidi A.H., and Al-Jumaily H. A. A., 2020. Geochemistry and environmental assessment of heavy metals in surface soil in Al-Hawija, Southwest Kirkuk. Iraqi Geological Journal, 53 (2E), 36-61.

Alloway, B. J., 1990. Heavy metals in soils. John Wiley and Sons, Inc. New York, ISBN 0470215984

Alloway, B. J., Zhang, P., Mott, C., Smith, S. R., Chambers, B. J., Nicholson, F. A., Calton-Smith, C., and Andrews A. J., 2000. The vulnerability of soils to pollution by heavy metals (Final Report for MAFF Project No. SP0127), London: MAFF.

Baran, A., Wieczorek, J., and Mazurek, R., 2018. Potential ecological risk assessment and predicting zinc accumulation in soils. Environment Geochemical Health, 40, 435-450.

Barbieri, M., Nigro, A., and Sappa, G., 2015. Soil contamination evaluation by Enrichment Factor (EF) and Geoaccumulation Index (Igeo). Department of Civil, Building and Environmental Engineering, Sapienza University of Rome, Via Eudossiana - 00184 Rome, Italy. Department of Civil, Building and Environmental Engineering, Sapienza University of Rome, Via Eudossiana - 00184 Rome, Italy. arbieri M, Nigro A, Sappa G. /Senses Science, 2 (3), 94-97.

Bellen, R.C., Dunington, H.V., Wetzel, R., and Morton, D.M., 1959. Lexique sratigraphique international, Asie Fascicalc. 100, Iraq Central, National researcher scientifique, Paris, 333 pp.

Beygi, M., and Jalali, M., 2018. Background levels of some trace elements in calcareous soils of the Hamedan Province, Iran. CATENA, 162, 303-316 pp.

Buday, T., 1980. The Regional Geology of Iraq: stratigraphy and paleogeography. Dar Al-Kutib Pub. House, Univ. of Mosul, Iraq, $444 \mathrm{pp}$.

Butu, A. W., 2013. Concentration of metal pollutants in river Kubanni, Zaria, Nigeria. Journal National Sciences Resources, 3, 19-25. 
Chauhan, S.S., Thakur, R., and Sharma, G.D., 2008. Nickel: its availability and reactions in soil. Journal of Industrial Pollution Control, 24, (1), 1-8.

Daniel, N.O. B., Tandoh, K., Brako, K., and Blestmond, A., 2019. Geochemistry of minor and trace elements in soils of Akuse Area, Southeastern Ghana, Geosciences, 9 (1), 8-17.

Davenport, A., 2020. Trace Elements in Chronic Kidney Disease. Chronic Renal Disease, 703-717pp.

Ding, Z., Li, Y., Sun, Q., and Zhang, H., 2018. Trace elements in soils and selected agricultural plants in the Tongling Mining Area of China. International Journal of Environmental Research and Public Health, 15 (202), 1-12.

Edem, C.A., Akpan, B., and Dosunmu, M. I .1 SSchutzendubel, A. and Polle, A., 2002. Plant responses to abiotic stresses: heavy metal- induced oxidative stress and protection by mycorrhization. Joumal of Experimental Botany, 53, (372), 1351-1365.

Goldschmidt, V.M., 1958. Geochemistry. Oxford University Press, London.

Hakanson, L., 1980. An ecological risk index for aquatic pollution control a sedimentological approach. Water Resource, 14, 975-1001.

Haris, H., Looi, L. J., Aris, A. Z., Mokhtar, N. F., Ayob, N. A. A., Yusoff, F.M., and Praveena, S.M., 2017. Geo-accumulation index and contamination factors of heavy metals $(\mathrm{Zn}$ and $\mathrm{Pb})$ in urban river sediment. Environmental Geochemistry and Health, 39 (6), 1259-1271.

Harrison, P.L., and Ward, S., 2001. Elevated levels of nitrogen and phosphorus reduce fertilization success of gametes from scleractinian reef corals. Marine Biology. 139, 1057-1068.

Ibrahim, S.A., Abed, M.F., and Al-Tawash, B.S., 2018. Calculation of pollution indicators and health hazards of heavy elements in surface soils in Samarra City. Iraqi Journal of Science, 59 (3B), 1419-1429.

Jassim, S. Z. and Goff, T., 2006. Phanerozoic development of the northern Arabian Plate, In: Jassim S.Z., Goff, J. C., Geology of Iraq, publication of Dolin, Prague and Moravian Museum, Brno, 341 pp.

Kabata-Pendias, A., and Mukherjee, A.B., 2007. Trace elements from soil to human. Berlin: Springer.

Kassab, I. I. M and Jassim, S. Z., 1980.The Regional Geology of Iraq, general directorate for geological survey and mineral, Baghdad, Iraq.

Kimbrough, R.D., and Krouskas, C.A., 2012. Contribution of lead in soil to children's lead burden, an update, Chemical Speciation and Bioavailability, 24 (2), 105-112.

Liu, H., Liu, G., Zhou, C., Yuan, Z., and Da, C., 2017. Geochemical speciation and ecological risk assessment of heavy metals in surface soils collected from the Yellow River Delta National Nature Reserve, China. Hum. Ecol. Risk Assess., 23, 1585-1600.

Mitchell, R. L., 1964. In: Chemistry of the Soil. (F.E. Bear, ed.), 2nd, 320-368pp. Reinhold, New York.

Morse, N., Walter, M.T., Osmond, D., and Hunt, W., 2016. Roadside soils show low plant available zinc and copper concentrations. Environmental Pollution, 209, 30-37.

Muller, G., 1969. Index of geoaccumulation in sediments of the Rhine River: Geology Journal, 2, 108-118.

Newaz, K.K., Pal, S.K., Hossain, S., and Karim, A., 2021. Evaluation of heavy metal pollution risk associated with road sediment. Environmental Engineering Resource, 26 (3), 1226-1025.

Oladeji, S.O., and Saeed,M.D., 2015. Assessment of cobalt levels in wastewater, soil and vegetable samples grown along Kubanni stream channels in Zaria, Kaduna State, Nigeria. African Journal of Environmental Science and Technology. 9 (10), 765-772.

Pavlin, M., Jaćimović, R., Stergaršek, A., Frkal, P., Koblar, M. and Horvat, M., 2018. Distribution and accumulation of major and trace elements in gypsum samples from lignite combustion power plant. American Journal of Analytical Chemistry, 9, 602-621.

Rankama, K. and Sahama, Th.G., 1950. Geochemistry. University of Chicago Press, Chicago, 912pp.

Salman, S. A., Zeid, S. A. M., Seleem, E. M. M., and Abdel-Hafiz, M.A., 2019. Soil characterization and heavy metal pollution assessment in Orabi farms, El Obour, Egyptian Bulletin National Resources Center., 43 (42).

Scheinost, A. C., 2005. Metal Oxides. Encyclopedia of Soils in the Environment, 428-438.

Shehzad, M.T., Murtaza, G., Shafeeque, M., Sabir, M., Nawaz, H., and Khan, M.J., 2019. Assessment of trace elements in urban topsoils of Rawalpindi-Pakistan: a principal component analysis approach. Environmental Monitoring and Assessment, 191 (2). 
Singh, R., Ahirwar, N. K., Tiw, J. and Athak, J., 2018. Review on Sources and Effect of Heavy Metal in Soil: Its Bioremediation. Department of Biological Sciences, Faculty of Science and Environment, Mahatma Gandhi Chitrakoot Gramodaya Vishwavidyalaya, Chitrakoot, Madhya Pradesh, India. Impact: International Journal of Research in Applied, Natural and Social Sciences, 2347-4580, 1-22.

Srinivas, T. N., Rao, S. R., and Kumar, K. S., 2009. Trace metal accumulation in vegetables grown in industrial and semi urban area: a case study. Applied Ecology Environmental Resources, 7, 131-139.

Sun, L., Carey, M., Yang, L., Chen, L.-D., Li, S.-J., Zhao, F.-K., and Meharg, A. A., 2018. Source Identification of Trace Elements in Peri-urban Soils in Eastern China. Exposure and Health.

Sun, Y., Zhou, Q., Xie, X., and Liu, R., 2010. Spatial, sources and risk assessment of heavy metal contamination of urban soils in typical regions of Shenyang, China. Journal of Hazardous Materials, 174 (1-3), 455-462.

Wedepohl, K. H., 1995. The composition of the continental crust. Geochimica et Cosmochimica Acta, 59 (7), 1217-1232.

Wieczorek, J., Baran, A., and Urbański, K., 2018. Assessment of the pollution and ecological risk of lead and cadmium in soils. Environment Geochemical Health, 40, 2325-2342.

Wong, C.S.C., Li, X., and Thornton, I., 2006. Urban environmental geochemistry of trace metals. Environmental Pollution, 142 (1), 1-16.

Wu, H., He, Y., Hou, Z., and Li, S., 2014. Composition of plagioclase in Dabie Early Cretaceous granitoids: influence of fractional crystallization on whole-rock $\mathrm{Sr}-\mathrm{CaO}$ correlations. Chinese Science Bulletin, 59(34), 4809-4815.

Yasmeen, K., Versiani, M., Arain, R., Haque, Q., Khan, N., Ali, S., and Langha, A., 2010. Enhanced metal levels in vegetables and farm soil irrigated with industrial wastewater. Journal Applied Science Environment. Manage, 14, 95-99.

Zhao, X., Tong M., He, Y., Han, X., and Wang, L., 2021. A comprehensive, locally adapted soil quality indexing under different land uses in a typical watershed of the eastern Qinghai-Tibet. Ecological Indicators, 125.

Zovko, M., and Romic, M., 2011. Soil contamination by trace metals: Geochemical Behavior as an element of risk assessment. Earth and Environmental Sciences, 437-456. 